Tohoku J. exp. Med., 1977, 121, 275-280

\title{
Biochemical Differences between Human Malignant and Benign Insulinoma Tissues
}

\author{
Ichiro Nakazawa, Akira Ohneda and Kiyomi Miura \\ The Third Department of Internal Medicine, Tohoku University \\ School of Medicine, Sendai
}

\begin{abstract}
Nakazawa, I., Omneda, A. and Mura, K. Biochemical Differences between Human Malignant and Benign Insulinoma Tissues. Tohoku J. exp. Med., 1977, 121 (3), 275-280 - Five cases of malignant insulinoma and 2 cases of benign insulinoma were studied lipid-chemically. Tissues were collected by surgical operation or biopsy under peritoneoscopy. The total lipid was extracted from each tissue, and one part of each total lipid was separated into phospholipid, triglyceride and other lipid fractions by a thin-layer chromatography (TLC) on silica gel. The fatty acid composition and fatty acid content of each lipid fraction were measured by a gas-liquid chromatography (GLC). The most remarkable difference between malignant and benign insulinoma tissues was a higher percentage value of eicosatrienoic acid in the phospholipid of malignant insulinoma tissues when compared with that of non-malignant insulinoma tissues; the values mentioned above distributed between 9.82 and 3.32 in 5 malignant cases, but were 2.89 and 2.57 in 2 benign cases. Those changes in the phospholipid fatty acid composition of malignant insulinoma tissues may represent one of the mechanisms of malignant growth in the malignant neoplastic tissue. - human insulinoma; neoplastic tissue; phospholipid
\end{abstract}

We have been studying the lipid-chemical features of human malignant neoplastic tissues with the aim to clarify the biochemical characteristics of malignant neoplastic growth and to obtain a clue for the chemotherapy against cancer. In this respect, it is important to clarify biochemical differences between human malignant neoplastic and benign neoplastic tissues. For example, Nakazawa et al. $(1973,1976)$ reported on lipid-chemical differences between the cancerous tissue of the human large intestine and the adenomatous polypous tissue which is considered as a precancerous condition by some authors (Morson 1968; Muto et al. 1975). In this report, we deal with lipid-chemical features of human malignant and benign insulinoma tissues which have revealed a considerable difference.

\section{Materials and Methods}

Tissues. From 2 cases (Cases No. 1 and No. 2 in Table 1) of malignant insulinoma with liver metastasis, metastatic lesions in the liver were obtained by a needle biopsy under peritoneoscopy, for the safety of the patients and the acquirement of good samples.

Received for publication, October 14, 1976.

Abbreviation: The fatty acids are designated by chain length and number of double bonds. For example, $\mathrm{C}_{20}$, stands for a fatty acid with 20 carbon atoms and 3 double bonds. 
Each biopsied specimen was divided into two parts and one part was examined histologically and the other part lipid-chemically. In one case of malignant insulinoma with liver metastasis (Case No. 3 in Table 1), its pancreatic tumor tissue, its normal pancreatic tissue surrounding the tumor and the metastatic lesion in the liver were excised by surgical operation. From 2 cases of malignant insulinoma without liver metastasis (Cases No. 4 and No. 5 in Table 1) and 2 cases of benign insulinoma (Cases No. 6 and No. 7 in Table 1), insulinoma tissues and the respective normal pancreatic tissues surrounding lesions were collected by surgical operation. All tissues thus obtained were examined histologically. The tumor tissues of Cases No. 4 and No. 5 showed the histological findings of perivascular infiltration by insulinoma cells, so that they were diagnosed as malignant insulinoma. Cases No. 6 and No. 7 represented a typical benign insulinoma.

Reagents. All organic solvents were redistilled. Silica-Gel-G nach Stahl for a thinlayer chromatography (TLC) was purchased from Merk Chemical Company. Standards for a gas-liquid chromatography (GLC) was obtained from Applied Science Laboratories, Ine, State College, Pennsylvania, USA. Other chemicals used were obtained commercially and were of extra pure grade.

Extraction of tissue lipids. Each tissue collected, after weighing, was homogenized with methanol-chloroform $(1: 2 \mathrm{v} / \mathrm{v})$ by a Potter-type glass homogenizer at room temperature, and total lipid was extracted by the method of Folch et al. (1957). The homogenate was filtered and dried up in $\mathrm{N}_{2}$ gas under a reduced pressure, and redissolved in methanol-chloroform. The total lipid was divided into two precisely measured parts and each was used for the analysis of the total lipid and lipid fractionation by TLC. TLC was performed by the method of Vogel et al. (1962), using a mixture of petroleum ether, diethylether and acetic acid $(90: 10: 1 \mathrm{v} / \mathrm{v})$ as a developing solvent. Each lipid fraction was scraped off the plate and saponified with $10 \% \mathrm{KOH}$-methanol at $37^{\circ} \mathrm{C}$ for $48 \mathrm{hr}$. Then, the fatty acids of each lipid fraction were extracted and methylated by diazomethane. Before applying to GLC, a definite amount of methyl erucate was added to the samples as an internal standard. Further details of the methods for TLC and GLC analyses were described previously (Nakazawa and Yamagata 1971; Nakazawa et al. 1973).

Also, the blood glucose of the capillary blood was measured by the glucose oxidase method (Teller 1956) and the plasma insulin was measured by the radioimmunoassay according to Morgan and Lazarow (1962).

\section{Results and Discussion}

Insulin content of tumor. As shown in Table 1, the tissue content of insulin was higher in the cases of benign insulinoma as compared with that of the cases of malignant insulinoma. At present, the underlying mechanism of this difference is unclear.

Maximum fasting immunoreactive insulin. As shown in Table 1, this value was lower in the malignant non-metastatic cases (Cases No. 4 and No. 5 in Table 1) when compared with the metastatic or benign cases. However, the reason why such a difference was seen in the present cases is unknown, at present.

Fatty acid composition of the total lipid. As shown in Table 2, there was no remarkable difference in the fatty acid composition between malignant and nonmalignant insulinoma tissues. Interestingly, however, remarkable differences were recognized between the tissues of insulinoma and the respective normal pancreatic tissues neighboring the insulinoma in both benign and malignant cases, when surveyed on both tissues. Namely, a remarkable decrease of $\mathrm{C}_{\mathbf{1 4 : 0}}$ and $\mathrm{C}_{\mathbf{1 8 : 2}}$ 
TABLE 1. Clinical data of insulinoma cases

\begin{tabular}{|c|c|c|c|c|c|c|c|c|c|}
\hline \multirow{2}{*}{$\begin{array}{l}\text { Case } \\
\text { No. }\end{array}$} & \multirow[b]{2}{*}{ Name } & \multirow{2}{*}{$\begin{array}{c}\text { Age } \\
\text { (years) }\end{array}$} & \multirow[b]{2}{*}{ Sex } & \multirow{2}{*}{$\begin{array}{l}\text { Liver* } \\
\text { Meta. }\end{array}$} & \multirow{2}{*}{$\begin{array}{c}\text { Minit } \\
\mathrm{FBG} \\
(\mathrm{mg} / 100 \mathrm{ml})\end{array}$} & \multirow{2}{*}{$\begin{array}{c}\text { Maxit }_{+} \\
\text {IRI } \\
(\mu \mathrm{U} / \mathrm{ml})\end{array}$} & \multicolumn{3}{|c|}{ Tumor } \\
\hline & & & & & & & $\begin{array}{l}\text { Size } \\
(\mathrm{mm})\end{array}$ & $\begin{array}{c}\text { Insulin } \\
(\mathrm{U} / \mathrm{g})\end{array}$ & Histology \\
\hline 1 & S.Y. & 54 & Male & + & 22 & 296 & - & - & $\begin{array}{l}\text { Metastasis } \\
\text { to the liver }\end{array}$ \\
\hline 2 & T.S. & 70 & Female & + & 19 & 202 & 一 & 一 & $\begin{array}{l}\text { Metastasis } \\
\text { to the liver }\end{array}$ \\
\hline 3 & R.O. & 22 & Female & + & 24 & 122 & $30 \times 45$ & 7.05 & Malignant \\
\hline 4 & K.K. & 24 & Male & - & 29 & 68 & $10 \times 10$ & 4.9 & Malignant \\
\hline 5 & F.M. & 40 & Female & - & 35 & 45 & $32 \times 30$ & 10.5 & Malignant \\
\hline 6 & S.K. & 34 & Female & - & 35 & 183 & $10 \times 10$ & 18.1 & Benign \\
\hline 7 & S.S. & 62 & Male & - & 11 & 203 & $16 \times 15$ & 17.3 & Benign \\
\hline
\end{tabular}

* Liver metastasis † Minimum fasting blood glucose

+ Maximum fasting immunoreactive insulin

TABLE 2, The total lipid fatty acid composition of insulinoma and neighboring pancreatic tissues $(\%)$

\begin{tabular}{|c|c|c|c|c|c|c|c|c|c|c|}
\hline $\begin{array}{l}\text { Case } \\
\text { No. }\end{array}$ & Diagnosis & Tissue & $\mathrm{C}_{14: 0}$ & $\mathrm{C}_{16: 0}$ & $G_{16: 1}$ & $C_{18: 0}$ & $\mathrm{C}_{18: 1}$ & $C_{19: 2}$ & $\mathrm{C}_{20: 3}$ & $\mathrm{C}_{20: 4}$ \\
\hline 1 & $\begin{array}{l}\text { Malignant } \\
\text { insulinoma } \\
\text { with liver } \\
\text { metastasis }\end{array}$ & $\begin{array}{l}\text { Metastatic } \\
\text { to liver }\end{array}$ & 1.14 & 23.15 & 5.53 & 13.82 & 21.90 & 14.02 & 3.25 & 7.05 \\
\hline 2 & $\begin{array}{l}\text { Malignant } \\
\text { insulinoma } \\
\text { with liver } \\
\text { metastasis }\end{array}$ & $\begin{array}{c}\text { Metastatic } \\
\text { to liver }\end{array}$ & 0.61 & 24.37 & 3.77 & 12.55 & 23.34 & 4.91 & 7.71 & 9.52 \\
\hline \multirow[t]{3}{*}{3} & $\begin{array}{l}\text { Malignant } \\
\text { insulinoma }\end{array}$ & $\begin{array}{c}\text { Metastatic } \\
\text { to liver }\end{array}$ & 0.46 & 21.14 & 1. 72 & 10.87 & 17.78 & 13.57 & 4.09 & 20.93 \\
\hline & with liver & Insulinoma & 0.60 & 20.59 & 2.46 & 13.32 & 20.88 & 14.09 & 4.34 & 16.08 \\
\hline & metastasis & $\begin{array}{l}\text { Normal } \\
\text { pancreatic }\end{array}$ & 1.05 & 19.94 & 2.85 & 12.13 & 20.32 & 30.13 & 0.79 & 6.14 \\
\hline \multirow[t]{2}{*}{4} & Malignant & Insulinoma & 0.69 & 17. 74 & 3.88 & 13.89 & 24.68 & 11.76 & 9.43 & J1. 54 \\
\hline & $\begin{array}{l}\text { insulinoma } \\
\text { without } \\
\text { hepatic } \\
\text { metastasis }\end{array}$ & $\begin{array}{l}\text { Normal } \\
\text { pancreatic }\end{array}$ & 1. 20 & 23.50 & 3.56 & 11.28 & 22.60 & 20.98 & 0.79 & 4.27 \\
\hline 5 & $\begin{array}{l}\text { Malignant } \\
\text { insulinoma } \\
\text { without } \\
\text { hepatic } \\
\text { metastasis }\end{array}$ & Insulinoma & 3.21 & 26.65 & 8.99 & 5.04 & 39.35 & 12.00 & 0.46 & 1.86 \\
\hline \multirow[t]{2}{*}{6} & Benign & Insulinoma & 0.54 & 21.05 & 2.75 & 14.52 & 20.86 & 12.03 & 3.01 & 15.55 \\
\hline & insulinoma & $\begin{array}{l}\text { Normal } \\
\text { pancreatic }\end{array}$ & 3.85 & 30.01 & 6.59 & 6.11 & 35.02 & 13.00 & 0.33 & 1. 10 \\
\hline \multirow[t]{2}{*}{7} & Benign & Insulinoma & 1.13 & 24.94 & 8.00 & 8.94 & 30.34 & 13.25 & 1.55 & 8.24 \\
\hline & insulinoma & $\begin{array}{l}\text { Normal } \\
\text { pancreatic }\end{array}$ & 2.43 & 25.35 & 7.98 & 6.68 & 24.58 & 21.56 & 1.23 & 4.44 \\
\hline
\end{tabular}


TABLE 3. The phospholipid fatty acid composition of insulinoma and neighboring normal pancreatic tissues $(\%)$

\begin{tabular}{|c|c|c|c|c|c|c|c|c|c|c|}
\hline $\begin{array}{l}\text { Case } \\
\text { No. }\end{array}$ & Diagnosis & Tissue & $\mathrm{C}_{14: 0}$ & $\mathrm{C}_{16: 0}$ & $\mathrm{C}_{16: 1}$ & $\mathrm{C}_{18: 0}$ & $C_{18: 1}$ & $\mathrm{C}_{18: 2}$ & $\mathrm{C}_{20: 3}$ & $\mathrm{C}_{20: 4}$ \\
\hline 1 & $\begin{array}{l}\text { Malignant } \\
\text { insulinoma } \\
\text { with liver } \\
\text { metastasis }\end{array}$ & $\begin{array}{l}\text { Metastasized } \\
\text { to liver }\end{array}$ & 0.47 & 23.70 & 3.42 & 18.08 & 21.47 & 11. 39 & 4.56 & 9.62 \\
\hline 2 & $\begin{array}{l}\text { Malignant } \\
\text { insulinoma } \\
\text { with liver } \\
\text { metastasis }\end{array}$ & $\begin{array}{l}\text { Metastasized } \\
\text { to liver }\end{array}$ & 0.57 & 26.17 & 3.94 & 14.97 & 25.98 & 4.92 & 8.16 & 10.31 \\
\hline \multirow[t]{3}{*}{3} & $\begin{array}{l}\text { Malignant } \\
\text { insulinoma }\end{array}$ & $\begin{array}{l}\text { Metastasized } \\
\text { to liver }\end{array}$ & 0.27 & 20.12 & 1.37 & 17.62 & 18.96 & 12.07 & 3.51 & 18.31 \\
\hline & with liver & Insulinoma & 0.47 & 20.71 & 2.15 & 16.17 & 20.68 & 13.57 & 3.97 & 14.61 \\
\hline & metastasis & $\begin{array}{l}\text { Normal } \\
\text { pancreatic }\end{array}$ & 0.34 & 21.40 & 1.77 & 15.23 & 15.49 & 33.04 & 0.99 & 6.57 \\
\hline \multirow[t]{2}{*}{4} & Malignant & Insulinoma & 0.49 & 18.34 & 3.43 & 14.52 & 25.19 & 11.50 & 9.82 & 11.97 \\
\hline & $\begin{array}{l}\text { insulinoma } \\
\text { without } \\
\text { liver } \\
\text { metastasis }\end{array}$ & $\begin{array}{l}\text { Normal } \\
\text { pancreatic }\end{array}$ & 0.21 & 23. 94 & 2. 28 & 14.40 & 16.37 & 25.82 & 1.47 & 6.67 \\
\hline 5 & $\begin{array}{l}\text { Malignant } \\
\text { insulinoma } \\
\text { without } \\
\text { liver } \\
\text { metastasis }\end{array}$ & Insulinoma & 0.53 & 21.99 & 2.87 & 14.20 & 20.21 & 13.23 & 3.32 & 15.36 \\
\hline \multirow[t]{2}{*}{6} & Benign & Insulinoma & 0.49 & 21.97 & 3.04 & 13.94 & 21.29 & 11.61 & 2.89 & 15.44 \\
\hline & insulinoma & $\begin{array}{l}\text { Normal } \\
\text { pancreatic }\end{array}$ & 0.96 & 20.78 & 4.65 & 13.96 & 15.83 & 22.55 & 2.49 & 8.54 \\
\hline \multirow[t]{2}{*}{7} & Benign & Insulinoma & 0.58 & 20.95 & 4.17 & 14.63 & 20.35 & 11.88 & 2.57 & 14.84 \\
\hline & insulinoma & $\begin{array}{l}\text { Normal } \\
\text { pancreatic }\end{array}$ & 0.42 & 27.63 & 4.51 & 14.21 & 16.09 & 23.88 & 2.32 & 6.96 \\
\hline
\end{tabular}

and a remarkable increase of $\mathrm{C}_{20: 3}$ and $\mathrm{C}_{20: 4}$ in the insulinoma tissue were recognized, when compared with those of the respective neighboring normal pancreatic tissues in all cases (Cases No. 3, 4,6 and 7 in Table 2) where the insulinoma and the respective normal pancreatic tissues were investigated lipid-chemically. These results suggest the possibility that there are some lipid-chemical differences between the tissues of the whole normal pancreas and Langerhans' islands.

Fatty acid composition of phospholipid. As shown in Table 3, the most remarkable difference between malignant and benign insulinoma tissues was recognized for eicosatrienoic acid $\left(\mathrm{C}_{20: 3}\right)$. In 3 malignant cases with liver metastasis and 2 malignant cases without hepatic metastasis, values of the percentage of $\mathrm{C}_{20: 3}$ in the phospholipid fatty acid composition of insulinoma tissues were distributed between 3.32 and 9.82 and were larger than those of 2 benign cases (2.57 and 2.89). The values of percentage of $\mathrm{C}_{20: 3}$ of the phospholipid of the normal pancreatic tissue surrounding each tumor in 2 malignant cases were smaller than those of 2 benign cases. Thus, when the ratio of percentage of $\mathrm{C}_{20: 3}$ of insulinoma tissue to that of the respective normal pancreatic tissue surrounding each tumor was calculated, the ratios in 2 malignant cases were 4.01 and 6.68 , but 
the ratios in 2 benign cases were 1.16 and 1.11. Furthermore, the values of percentage of $\mathrm{C}_{14: 0}, \mathrm{C}_{16: 0}$ and $\mathrm{C}_{20: 4}$ in the phospholipid fatty acid composition of the normal pancreatic tissue surrounding the malignant insulinoma were smaller than those of the cases of benign insulinoma, but the values for $\mathrm{C}_{18: 0}$ and $\mathrm{C}_{18: 1}$ in the malignant cases were larger than those in the benign cases. These results appear to suggest that even the normal and non-tumorous pancreatic tissues surrounding malignant insulinoma may be somewhat different lipid-chemically from those of the benign insulinoma cases. This problem is very important and further studies are necessary to clarify this question.

Furthermore, a remarkable decrease of $\mathrm{C}_{18: 2}$ and a remarkable increases of $\mathrm{C}_{18: 1}, \mathrm{C}_{20: 3}$ and $\mathrm{C}_{20: 4}$ in the phospholipid fatty acid composition of insulinoma tissues were recognized as compared with those of the respective normal pancreatic tissues surrounding the insulinoma. This result suggests the possibility that there is a distinct difference in the phospholipid fatty acid composition between the normal pancreatic tissue and the insulinoma tissue.

At present, it is difficult to explain completely the significance of the abovementioned changes of the phospholipid fatty acid composition in malignant growth.

TABLE 4. The triglyceride fatty acid composition of insulinoma and neighboring nomal pancreatic tissues $(\%)$

\begin{tabular}{|c|c|c|c|c|c|c|c|c|}
\hline $\begin{array}{l}\text { Case } \\
\text { No. }\end{array}$ & Diagnosis & Tissue & $\mathrm{C}_{14: 0}$ & $\mathrm{C}_{16: 0}$ & $\mathrm{C}_{1 \mathrm{I}: 1}$ & $\mathrm{C}_{18: 0}$ & $C_{18: 1}$ & $\mathrm{C}_{18: 2}$ \\
\hline 1 & $\begin{array}{l}\text { Malignant } \\
\text { insulinoma } \\
\text { with liver } \\
\text { metastasis }\end{array}$ & $\begin{array}{l}\text { Metastasized } \\
\text { to liver }\end{array}$ & 4. 22 & 30.42 & 14.37 & 9.16 & 32.58 & 9.16 \\
\hline 2 & $\begin{array}{l}\text { Malignant } \\
\text { insulinoma } \\
\text { with liver } \\
\text { metastasis }\end{array}$ & $\begin{array}{l}\text { Metastasized } \\
\text { to liver }\end{array}$ & 1.38 & 32.66 & 7.81 & 15.40 & 36.81 & 5.91 \\
\hline \multirow[t]{3}{*}{3} & $\begin{array}{l}\text { Malignant } \\
\text { insulinoma }\end{array}$ & $\begin{array}{l}\text { Metastasized } \\
\text { to liver }\end{array}$ & 2. 31 & 35.20 & 4.99 & 19.16 & 28.26 & 9.91 \\
\hline & with liver & Insulinoma & 2.02 & 22.01 & 7.52 & 8.92 & 40.24 & 18.92 \\
\hline & metastasis & $\begin{array}{l}\text { Normal } \\
\text { pancreatic }\end{array}$ & 2.42 & 21.18 & 5.42 & 5.77 & 43.72 & 18.52 \\
\hline \multirow[t]{2}{*}{4} & Malignant & Insulinoma & 5.68 & 33.16 & 6.32 & 13.16 & 34.74 & 6.95 \\
\hline & $\begin{array}{l}\text { insulinoma } \\
\text { without } \\
\text { liver } \\
\text { metastasis }\end{array}$ & $\begin{array}{l}\text { Normal } \\
\text { pancreatic }\end{array}$ & 3.40 & 27.78 & 6.01 & 8.35 & 38.13 & 12.64 \\
\hline 5 & $\begin{array}{l}\text { Malignant } \\
\text { insulinoma } \\
\text { without } \\
\text { liver } \\
\text { metastasis }\end{array}$ & Insulinoma & 3.50 & 27.64 & 9.69 & 3.32 & 40.04 & 12.19 \\
\hline \multirow[t]{2}{*}{6} & Benign & Insulinoma & 3.19 & 27.28 & 5.18 & 10.42 & 30.42 & 9.55 \\
\hline & insulinoma & $\begin{array}{l}\text { Normal } \\
\text { pancreatic }\end{array}$ & 4. 46 & 30.18 & 7.71 & 4.97 & 38.83 & 11.71 \\
\hline \multirow[t]{2}{*}{7} & Benign & Insulinoma & 3.77 & 28.08 & 12.08 & 3.43 & 36.88 & 12.99 \\
\hline & insulinoma & $\begin{array}{l}\text { Normal } \\
\text { pancreatic }\end{array}$ & 2.97 & 28.16 & 9.51 & 4.38 & 36.54 & 16.18 \\
\hline
\end{tabular}


However, recently Horwitz et al. (1974) reported that altering the fatty acid composition of cellular phospholipid changes the transition temperature for agglutinability by wheat germ agglutinin or concanavalin A. Thus, the results of the present study suggest that the change of the phospholipid fatty acid composition may play a role, at least in part, in changing the character of benign growth to that of malignant growth.

Triglyceride fatty acid composition. As shown in Table 4, no remarkable difference was recognized between malignant and benign insulinoma tissues. However, an increase of the value of percentage of $\mathrm{C}_{18: 0}$ and a decrease of the values of percentage of $\mathrm{C}_{14: 0}$ and $\mathrm{C}_{16: 1}$ in the normal pancreatic tissues surrounding the malignant insulinoma were recognized when compared with those of benign insulinoma. These results, as well as the results obtained for the phospholipid fatty acid composition, suggest the possibility that there might be some lipidchemical differences between the pancreatic tissues associated with malignant and benign insulinoma. Further studies are needed, however, to account for those speculations.

\section{Acknowledgment}

We wish to express our thanks to Professor T. Sato and his staff, the First Department of Surgery, Tohoku University School of Medicine, for their cooperation in collecting the surgically excised tissues. Also, we would like to acknowledge Professor Y. Fuknoka and Dr. K. Abe, Central Clinical Laboratory, Tohoku University School of Medicine, for their kind help to this work. We thank Professor Y. Goto, the Third Department of Internal Medicine, Tohoku University School of Medicine, for his eritical reading of the manuscript.

\section{References}

1) Folch, J., Lees, M. \& Sloane Stanley, G.H. (1957) A simple method for the isolation and purification of total lipides from animal tissues. $J$. biol. Chem., 226. 497-509.

2) Horwitz, A.F., Hatten, M.E. \& Burger, M.M. (1974) Membrane fatty acid replacements and their effect on growth and lectin-induced agglutinability. Proc. nat. Acad. Sci. (Wash.), 71, 3115-3119.

3) Morgan, C.R. \& Lazarow, A. (1962) Immunoassay of insulin using a two-antibody system. Proc. Soc. exp. Biol. Med. (N.Y.), 110, 29-32.

4) Morson, B.C. (1968) Precancerous and early malignant lesions of the large intestine. Brit. J. Surg., 55, 726-731

5) Muto, T., Bussey, H.J.R. \& Morson, B.C. (1975) The evolution of cancer of the colon and rectum. Cancer, 36, 2251-2270.

6) Nakazawa, I. \& Yamagata, S. (1971) Biochemical changes of the lipid in biopsied livers of patients with malignant neoplastic diseases. Tohoku J. exp. Med., 103, 129-139.

7) Nakazawa, I., Yamagata, S. \& Watanabe, H. (1973) Lipid-chemical differences between human cancerous and adenomatous polypous tissues in the large intestine. Tohoku J. exp. Med., 110, 23-32.

8) Nakazawa, I., Yamagata, S. \& Watanabe, H. (1976) Further studies on lipidchemical differences between cancerous and adenomatous polypous tissues in the human large intestine. Tohoku J. exp. Med., 118 (Suppl.), 117-125.

9) Teller, J.D. (1956) Direct, quantitative colorimetric determination of serum or plasma glucose. Abstracts of Papers, $130 t h$ Meeting, Amer. chem. Soc., 69 c.

10) Vogel, W.C., Doizaki, W.M. \& Zieve, L. (1962) Rapid thin-layer chromatographic separation of phospholipid and neutral lipids of serum. J. Lipid Res., 3, 138-140. 